\title{
III. Observations on the circumstances which occasioned the Death of Fisher, Bishop of Rochester; in a Letter from JoHN BRUce, Esq. F.S.A. to 'номал Амуот, Esq. F.R.S., Treasurer.
}

Read 24th November, 1831.

MY DEAR SIR,

Francis-street, Golden-square, September 1831.

FEW men have suffered the extreme penalty of the law under circumstances more calculated to arouse general commiseration, than those which attended the death of Fisher, Bishop of Rochester. It has nevertheless happened, that whilst the most trifling circumstances relating to his illustrious companion in misfortune have been dwelt upon with great minuteness, the fall of Fisher has not been investigated with any thing like a proportionable diligence. The chief reason for this marked difference may be found, I imagine, in the personal character of Sir Thomas More, compounded as it was of qualities more showy and attractive than the meek and Christian virtues of Bishop Fisher. The discrepancies and contradictions in the accounts of the proceedings against Fisher given by our best historians a are so numerous, that $I$ have thought a careful statement of the circumstances which accompanied his fall, partly derived from MSS. which do not appear to have been printed, would probably be acceptable to

a The acts of parliament and other legal matters mixed up with the question seem to have confounded most of our historical writers. Many have shunned the question of Fisher's legal crime altogether; several have imagined that he was executed in pursuance of one of the acts of attainder against him, althongh they were merely for misprision of treason; and others have attributed his conviction to a refusal to take the oath of supremacy, which had no existence until the 1st year of Elizabeth. It would be an ungracious task to trace these errors home, or they might be assigned to names of considerable celebrity. 
you, and if you think the matter of sufficient general interest to merit the attention of the Society of Antiquaries, you will oblige me by submitting the following remarks to their notice.

It is well known that Fisher was a zealous defender of the Roman Catholic Church against the attacks of the Lutherans. He wrote against the new opinions with spirit and acuteness, and backed his arguments with the weighty evidence of an irreproachable and untainted life. In an age by no means distinguished either for morality or learning, he was at once eminent for virtue and respectable as a scholar. That he was an encourager of learning in others is well proved by his patronage of Erasmus, ${ }^{b}$ and his assiduity in the foundation of Christ's and St. John's Colleges in Cambridge, the Lady Margaret's professorships, and other scholastic endowments; and his personal affection for literature may be inferred from his collecting one of the best libraries in England, and also from his undertaking the study of Greek when the knowledge of that language was revived in England, although he was then upwards of 60 years of age. ${ }^{\mathrm{d}}$

His appointment to the Bishopric of Rochester arose out of some compunctious visitings of conscience in Henry VII. who, in writing to his mother the Countess of Richmond, confesses "that in his days he had promoted many a man unadvisedly," and "I wolde now," he proceeds, " make some recompencon to promote some good and vertuouse men ;" and therefore he wishes to appoint her confessor Master Fisher "for non other cause but for the grate and singular virtue that $I$ know and se in hym as well in conyng and natural wisdome, and specially for his good and vertuouse lyving." e

Fisher's reputation was equivalent to his merit. Henry VIII. held him in peculiar esteem, and inquired of Cardinal Pole whether in all his travels

b Butler's Life of Erasmus, pp. 65, 118. Erasmi Epist. p. 353. ed. Lond. 1642.

c Harl. MS. No. 7047, p. 17 , "He had the notablest library of books in all England, two long galleries full. The books were sorted in stalls, and a register of the names of every book at the end of every stall."

d Erasmi Epist. 522, 526.

e See the Letter in the Appendix to "the Funeral Sermon of Margaret Countess of Richmond." Ed. 170s, p. 41. 
he had ever found a prelate of equal worth and ability with the Bishop of Rochester. ${ }^{f}$

His friend and correspondent Erasmus makes frequent mention of him, and dwells with pleasure upon the blamelessness of his life, the peculiar kindness of his manners, his learning and noble-mindedness. 8

If judged by modern taste his sermons will be found to contain little that is attractive; but his contemporaries appear to have held his pulpit eloquence in high estimation. He preached upon the interment of the Countess of Richmond and of her son Henry VII. He was appointed to preach before Henry VIII. upon receipt of tidings of the victory of Flodden ${ }^{\mathbf{h}}$ he preached at St. Paul's Cross upon the public condemnation of Luther's doctrines, on the 12th May 1521, ${ }^{i}$ and is mentioned as the preacher upon several other peculiar and solemn occasions.

It appears in the volume of State Papers lately published, ${ }^{\mathrm{k}}$ that upon the first whisper of the meditated divorce between Henry and Katherine, Fisher, although unwilling to interfere, was applied to by the Queen for advice. He was afterwards one of her counsellors upon the hearing before the Legate at Black Fryars, ${ }^{1}$ and in that character first drew upon himself the displeasure of the King. The opposition, which there can be no doubt he offered conscientiously, against Henry's subsequent proceedings, not merely eradicated the King's former feeling of affection for him, but even increased his displeasure into dislike and hatred. In the convocation and afterwards in the parliament, although almost alone, Fisher was a strenuous opponent to every measure which tended "to break the bonds of Rome," and, notwithstanding his advanced age and infirm health, appears to have maintained the contest eloquently and with vigour.

Fisher's constant opposition must have rendered him exceedingly troublesome to a Court little accustomed to have its measures thwarted, and the case of Elizabeth Barton, the Nun or Maid of Kent, was laid hold of by the King's advisers as affording an opportunity at any event of silencing if not of crushing him.

f Apol. Pol. p. 95, quoted in Lingard's Hist, of England, vol. vi. p. 274. Second edit.

g Erasmi Epist. p. 96, 515, 516.

h Lord Herbert, p. 40.

i Cott. MS. Vitellius, B. Iv. fol, 111.

k P. 198.

1 Hall, p. 758, edit. 1809. 
The crime of Elizabeth Barton consisted in assuming the character of a prophetess, and denouncing impending judgments against the King. ${ }^{\mathrm{m}}$ She declared that it had been revealed to her that the Almighty was displeased with the King, that if he proceeded with the divorce and married again he should be no longer King, that in the estimation of God he should not be King one hour, and that he should die a villain's death. Her prophetical career continued for several years, the exercise of her gift being by no means confined to political subjects, but extending to matters of a very miscellaneous and unimportant character. The paroxysm of a convulsive fit was the moment of her pretended inspiration, and she then uttered her insane predictions, sometimes in prose, sometimes in verse, and either in her own chamber with a few favoured hearers, or prostrate in a church before a multitude of eager listeners congregated together by previous appointment. Some ecclesiastics who found their account in her celebrity encouraged her in the opinion that she was divinely inspired, and sedulously extended her fame. Books were composed concerning her, a letter written in golden characters, which she was said to have received from Mary Magdalen, was exhibited to the faithful, and the Holy Maid of Kent, and the image of the Virgin in the Chapel of Court att Street, which she honoured with her peculiar regard, were objects of universal wonder and veneration.

In the opening of her prophetical career she was introduced to Wolsey and also to the King, and afterwards, when the divorce seemed determined upon, and the breach with Rome was becoming inevitable, her political prophesies were used for party purposes, and reported to Queen Katherine, to the Pope's envoys, and the heads of the Catholic party. Amongst others to whom they were communicated were Fisher and Sir Thomas More. We are so prone to forget that men's conduct should be estimated by the opinions and manners of their contemporaries, that we may feel surprise that men like these could ever have seriously listened to the delirious ravings of such a pretender to inspiration. It ought, however, to be borne in mind that a belief in extraordinary spiritual influences and revelations was then a

m Hall, p. sos. His account is taken from the Act of Parlianent by wlich she was attainted. 
portion of the general creed, and nothing proves the fact more clearly than that some of the wisest men of the time gave attention and credit to this poor half-witted woman. More addressed a letter to her ${ }^{\mathrm{n}}$ in which he styled her " right dearly beloved sister in our Lord God," and in a letter to Cromwell, he admits that he had "a great good opinion" of her, and had her " in great estimation," although in the same letter he mentions that she told him that the devil haunted her in the shape of a bird, which, when caught, turned out to be, as might be expected, "a very strange ugly-fashioned bird," so that " they were all afraid and threw him out at a window."

The prophesies of Barton were first taken notice of by the government in 1533, and after an investigation by Cranmer, Cromwell, and Hugh Latimer, then a priest, the Maid and her chief supporters were, in November, brought before "a very great assembly and Council of the Lords of the Realm," in the Star Chamber, and upon confession were sentenced $\mathrm{P}$ to " stand at Paules Crosse, wher thei with their awne handes should severally deliver, eche of them, to the preacher that should be appoynted, a bill declaring their subtle, craftie, and supersticious doynges. Which thyng the next Sondaie after they all above rehearsed, standyng on a stage at Paule's Crosse made for that purpose, did accomplishe." After this exhibition the culprits were conveyed to the Tower, and confined there without further proceedings until the next parliament.

The fact that Fisher and More had had some intercourse with the Maid having transpired, either upon the preliminary inquiry, or in the Star Chamber, Cromwell, at that time Secretary of State, dispatched Fisher's brother to him with a message of "heavy words" and "terrible threats" against him, advising him to write to the king a letter of submission, and crave pardon for his offences.

Instead of adopting this advice, Fisher wrote to Cromwell a letter, in which he justified his conduct, and declined to ask pardon for offences which he was ignorant of having committed. I am not aware that this letter is in

\footnotetext{
n Roper's More, Appendix, p. 106. Singer's edit.

p Hall, p. 806 .
}

- Ibid.

VOL. XXV. 
existence, but its contents may be gathered from a long answer to it by Cromwell, which is printed by Burnet from a draft amongst the Cotton MSS.4

The accusations brought by Cromwell against Fisher were, that he had heard and concealed the Maid's pretended political prophesies, and had kept up an intercourse with her, by several times sending his chaplains to her. It is difficult to conceive what legal crime could be justly imputed to Fisher, even supposing these accusations were true. Elizabeth Barton's contemporaries allowed the possibility of such an inspiration as she laid claim to, and the duty of a good man was therefore confined to the satisfaction of his conscience, by an examination of the evidence upon which the possession of the gift was sought to be established. This is the rule by which to judge of Fisher's conduct, and by which he endeavoured to justify himself. He admitted that he had heard of her prophesies, that he put any faith in them does not appear, but it is sufficiently evident that he entertained a very favourable opinion of the Nun, and perhaps was inclined to attribute to her some supernatural power. The general opinion of her sanctity; a belief that the ecclesiastics by whom she was surrounded, and who spoke loudly of her great boliness, were learned and religious men; the representations of Archbishop Warham, who believed in her visions and had spoken to Fisher concerning them; her own conduct during Fisher's interviews with her; and her answers to the questions he propounded to her by way of trial and examination, were the foundations of his good opinion or belief, whichever of them it ought to be called. That his inquiries did not lead to a discovery of the alleged fraud, and were not such as Cromwell considered proper for ascertaining the truth, ought certainly not to be imputed to him as crimes. His own personal satisfaction was his object, and in such a pursuit the judgment of any other man ought not to be the standard of right and wrong.

The most serious accusation against Fisher was, that he concealed these prophesies from the King. His answer was, that the Nun told him that she had herself communicated to the King what had been revealed to her, which he, knowing she had been with the King, believed to be true, and which 
was not stated to be otherwise. He also alleged that she spoke not of any evil that was to befal the King, other than by the ordinary visitations of Providence. These two points seem satisfactorily to get rid of the anomalous charge of improperly concealing a prophesy, but it may fairly be questioned whether the prophesies were not matter of public notoriety, and therefore incapable of concealment. If they were to be used for political purposes a considerable degree of notoriety was necessary to secure their end, and the act of attainder of Elizabeth Barton ${ }^{r}$ recites that Bocking and Dering "made, writ, and caused to be written, sondry books, bothe great and small, bothe printed and written," concerning Barton's revelations, and afterwards expressly states that the obnoxious revelations concerning the King were "written and expressed in the said bokes and volumes." How a charge could even be brought against Fisher for concealing that which was thus openly declared to the world, and above all, how such a charge could be introduced into an act of parliament which contains the statements I have quoted, seems not a little surprising.

The parliament met on the 15th January 1534, and it would seem that Fisher was particularly urged to attend by Cromwell, who in all probability informed him, that a bill was about to be introduced in which he would have a personal interest. Fisher was then at Rochester confined by illness, and on the 28th of January wrote to Cromwell a letter of excuse, which may be found amongst the Cotton MSS.s It does not appear to have been printed, and I shall therefore insert it in an Appendix. ${ }^{t}$ It is couched in very humble terms, informs Cromwell that he was labouring under an illness which had then lasted six weeks, and assures him that, if he could see in what plight he was, he would have some pity upon him. ${ }^{u}$

This letter seems to have been answered very speedily, for on the 31st January there is another letter from Fisher to Cromwell, which not having been

r Stat. 25 Henry VIII. cap. 12.

s Vespasian, F. XıII. fol. 154 b.

t Appendix, I.

u The compiler of the Cott. Catalogue appears to have had some doubt as to this letter. I imagine it is indisputable that the signature is that of Fisher, and the body of the letter agrees in the character of the hand-writing with other documents signed by Fisher. 
printed, I have also placed in the Appendix. x There is something very striking in the quiet, melancholy style in which this letter is written. He entreats that he may not be further called upon to answer Cromwell's letters, as he finds it altogether useless to do so, every thing he writes being attributed either to craft, or wilfulness, or to affection, or to unkindness against his sovereign. In allusion to some expressions in his former letter concerning the divorce, which had displeased the King, he says, "my study and purpose was specially to decline, that I should not be straited to offend his grace in that behalf, for then I must needs declare my conscience, the which, as then I wrote, I would be loth to do any more largely than I have done. Not that I condemn any other men's conscience, their conscience may save them, and mine must save me. Wherefore, good master Cromwell, I beseech you, for the love of God, be contented with this mine answer."

Cromwell's message to Fisher by his brother, and his subsequent letters, evince a very evident desire that Fisher should confess himself culpable, and submit to the mercy of the King, with an assurance of pardon if he would do so. Had he adopted this course it would have destroyed his freedom of action, and have rendered him incapable of offering any future opposition to the measures of the Court. It may be supposed that this was Cromwell's aim. Mr. Southey remarks $y$ that " the Bishop's persistance in refusing to do this was plainly a matter of obstinacy, not of conscience." It is a pity that a doctrine so dangerous should have so able an advocate. Fisher's conscience does not appear to have been of the pliable character then fashionable at Court, but his life and death attest its power over him, and it is indeed an extraordinary assertion that a man is to be denounced as obstinate, because, at the summons of a Secretary of State, and upon a promise of pardon, he did not acknowledge himself guilty of an undefinec offence, of the commission of which his own conscience did not accuse him.

On the 21st of Februaryz a bill of attainder against Barton and her associates was introduced into the House of Lords. She and the Ecclesias-

$x$ Cleopatra E. vi. fol. 161. Appendix, II.

y Book of the Church, vol. ii. p. 43.

z Lords' Journals, i. p. 68. 
tics who had spread abroad her pretended prophesies, were by this bill proposed to be declared guilty of high treason; and Fisher, More, and the others who, having had " knowledge of the said revelations had made concealment thereof, and uttered not the same to the King nor any of his Council," were to be attainted of misprision of treason, to suffer imprisonment at the King's pleasure, and forfeit all their personals.

Fisher being still confined by illness wrote to the Lords an able letter of justification, recapitulating much of the matter he had stated to Cromwell, and appealing to them that "as he never gave her any counsel in the matter, nor knew of any forging or feigning thereof, their great wisdoms would not think any default in him." This letter remains in MS. and is printed, but in some passages erroneously, in Collier's Ecclesiastical History. ${ }^{\mathrm{a}}$

The bill was read a first time on the 21st of February, the day of its introduction, and again a second time on the 26th of February. ${ }^{b}$ On the 27 th Fisher wrote to the King supplicating that he would "dismiss him from the trouble" which this bill occasioned to him. This letter is inserted in the Appendix, ${ }^{c}$ and as a composition of considerable interest and merit will well repay the trouble of perusal. It forcibly brings before us the rough and overbearing manner in which Henry was accustomed to treat his counsellors. In connection with this very bill against Elizabeth Barton, and to persuade the King to withdraw the name of Sir Thomas More out of it, Cranmer, the Chancellor, the Duke of Norfolk, and Cromwell, were unable to succeed until "upon their knees most humbly they besought him ;" at an after period of his life, in reproving the Chancellor Wriothesley, he termed him "a knave, fool, and beast, and bade him get out of his sight;" "e and this letter of Fisher, although it does not detail the particulars, proves that the "grievous letters and fearful words" which the King used towards Fisher when he had the honesty to express his opinion concerning the divorce, made no trifling impression upon the prelate.

a Cleopatra, E. vi. fol. 166. Collier's Eccles. Hist. ii. p. 87.

b J.ords' Journals, i. p. 69.

c Cleopatra, E. v1. fol. 162. Appendix, III.

d Roper's More, p. 68.

e Burnet, vol. i. p. 345. 
On the 6 th of March the bill was read a third time. ${ }^{f}$ More had in the mean time requested to be heard in his defence, and the Lords, out of respect to the man whose eloquence had so lately guided and enlightened them, directed inquiry to be made whether it squared with the King's mind that More and all those who were sought to be attainted of misprision of treason, should be examined in the Star Chamber to hear what they could say for themselves, with the exception of the Bishop of Rochester, whose answer had been received by letter. The particulars of what occurred may be seen in Roper's Life of More.g The only result of this honourable and uncourtly scruple was, that the name of More was withdrawn from the Bill, and on the 12th of March it was read a fourth time and passed by the Lords. ${ }^{\text {h }}$ On the 1; th March, having been expedited through the House of Commons, it was returned to the Lords. On the 20 th it was delivered to the Chancellor, whether for engrossment or for what other purpose does not appear. He brought it back on the 21 st, and I suppose the royal assent was given to it, according to the practice then usual, on the 30th March, when the King attended and put an end to the session. The Act is the 25th Henry VIII. cap. 12. It is needless to $d$ well upon the manifest injustice and breach of constitutional forms which distinguished the whole of this proceeding. It was the opening of a fearful tragedy, the turning of a page in our history which reflects equal disgrace upon the malignity of the King and the coldhearted suppleness of his advisers. That the King could obliterate the memory of former kindness, and close his heart against the entreaties of an infirm man who had long served his father and himself, whose pretended fault had been committed without fraud, and was followed by no evil consequences, and who in his extreme age declares that he merely sought " to prepare his soul to God, and to make it ready against the coming of death, and no more to come abroad into the world," $i$ is a proof how rapidly he was descending into the state of ferocious tyranny which distinguished the after portion of his life.

f Lords' Journals, i. p. 72.

h Journals, i. p. $74,76,77,78$. g P. 63, Singer's edit.

i Appendix, III. 
The same parliament which passed this act of attainder distinguished itself by placing upon the Statute Book the first of those instances of legislative folly by which the succession of the Crown was endeavoured to be secured by the force of strange oaths and the creation of new treasons. By the Statute of 25 Henry VIII. cap. 22, it was enacted that the marriage of Henry and Katherine was against the law of God, and void; and that the pro. cess before Cranmer, and his sentence of separation were lawful, notwithstanding the Pope's dispensation for the marriage, which was declared void. It was also enacted that the marriage with Anne Boleyn was lawful, and that no one could dispense with Grod's laws so as to render marriages within the Levitical degrees valid. By the fourth section power was given to the Ecclesiastical Courts to dissolve all such marriages, notwithstanding they might have been sanctioned by the Pope's dispensation. The throne was then settled upon Henry and his issue by Anne, and, after many enactments equally repugnant to the feelings and consciences of the Catholics, it was in conclusion enacted that every person by the commandment of the King should make an oath 'to maintain that act,' and all who refused to take such an oath should be held guilty of misprision of treason. When the King went to prorogue the parliament the Lords and Commons then present " most lovingly accepted and took such oath as was then devised," $\mathrm{k}$ and a commission was directed to the Chancellor, Cranmer, and the Dukes of Suffolk and Norfolk, empowering them to administer the oath to all other persons, according to a form then prescribed, and which was annexed to the commission. The oath thus prescribed, it may be remarked, goes very far beyond the direction of the Statute, which seems to authorize a mere general oath to maintain the objects of the Act, whereas the form entered in the Journals enbraces a variety of particulars as to the succession to the throne.

Soon after the close of the session the Commissioners required Fisher and many other ecclesiastics, together with Sir Thomas More, to appear before them and take the oath. The place appointed was the Archbishop's palace at Lambeth, and there on the 13th of April, 1534, they appeared.1 They

k Stat. 26 Hen. VIII. cap. 2. Lords' Journals, i. 82.

1 Strype's Cranmer, p. 26. Roper's More, p. 122. 
were called in before the Commissioners singly, and all we know of the interview, as far as Fisher is concerned, is its result. Fisher and More refused to take the oath tendered to them, and which was probably the same as was taken by the parliament; but both offered to swear to such portion of it as concerned the succession. They admitted that the parliament had a right to make such alterations in the descent of the Crown as were thought proper; but neither of them would allow the invalidity of the King's first marriage, the legality of the divorce, or of his marriage with Anne Boleyn. Their refusal appears to have been unanticipated; and, in order to obtain time to consider, and perhaps to consult with the King as to what course should be adopted, the Commissioners remanded them for four days. More was committed to the custody of the Abbot of Westminster; Fisher's place of detention does not appear. The 17th of April was the day appointed for their re-appearance, and on that day we find Cranmer writing to Cromwell from Croydon, referring to what had taken place on the former meeting, and urging the propriety of accepting their qualified oath. ${ }^{m}$ When Cranmer's advice was on the side of mercy it was often its fate to be unsuccessful, and it was so on the present occasion. The prisoners persisted in their refusal, and were both committed to the Tower.

On the next day Rowland Lee, then Bishop of Coventry and Lichfield, visited Fisher in the Tower, and on quitting him wrote a hasty note to Cromwell, which is printed in Strype's Cranmer. ${ }^{n}$ It shows the nature of the concessions Fisher was willing to make, and presents a striking picture of the condition of the man who was thus suddenly doomed to a rigorous imprisonment. " He is," says Lee, " as ye left him, ready to take the oath for the succession, and to swear never to meddle more in disputation of the validity of the matrimony, or invalidity, with the Lady Dowager, but that utterly to refuse. For as for the case of the prohibition Levitical, his conscience is so knit that he cannot send it off from him whatsoever betide him. And yet he will and doth profess his allegiance to our Sovereign Lord the King during his life." Such were his opinions; now mark how worthy a

m Cleopatra, E. vi. fol. 181. Strype's Cranmer, Appendix, p. 14.

n Cleopatra, E. vi. fol. 165. Strype's Cranmer, Appendix, p. I3. 
victim these lenient men had selected : "truly the man is nigh going, and doubtless cannot continue unless the King and his Council be merciful unto him. For the body cannot bear the clothes on his back, as God knoweth!" Fisher's bodily strength disappointed the expectation of his enemies. Sickness and age appear to have relaxed their virulence, and resigned the old man to the more certain vengeance of his persecutors.

The Statute of 25 Henry VIII. c. 22, in describing the nature of the oath to be taken by the people, enacted, that it should be an oath " truly, firmly, and constantly, without fraud or guile, to observe, fulfill, maintain, defend, and keep, to their cunning, wit, and uttermost of their powers, the whole effects and contents of that act." The Lord Chancellor and Mr. Cromwell, however, says Roper," "did of their own heads add more words unto it, to make it appear to the King's ears more pleasant and plausible, and that oath so amplified caused they to be administered to Sir Thomas More, and to all other throughout the realm." A proceeding more palpably illegal can scarcely be imagined; but Roper's account is borne out by indisputable authority. One result of this amplification was, that the imprisonment of More and Fisher, so far as it depended upon their refusal to take the amplified oath, was of course altogether illegal. The penalty inflicted by the Statute attached upon the refusal to take an oath of a particular description ; the amplified oath was not such an oath, and therefore that penalty did not attach upon the refusal to take it. An objection so entirely technical, one would have thought beneath the notice of the King's unscrupulous advisers, but they seem to have been influenced by the common weakness of endeavouring to give their injustice the sanction of legal forms, and as soon as the Parliament assembled, a bill was passed to remedy the defect.P After reciting the former statute, and that the Lords and Commons upon the last prorogation had taken, not the oath directed by the statute, but " such oath as was then devised," it was declared, that they meant and intended, that all the King's subjects should be bound to accept the same oath, "the tenour" of which, but not a copy of it, was then given in the form of an oath, and it was enacted that this new oath should be adjudged

o Roper's More, p. 74.

VOL. XXV. p 26 Henry VIII. cap. 2.
$\mathbf{L}$ 
to be the very oath that the Parliament meant and intended should be taken, and, upon the refusal to take which, the penalties denounced by the former act accrued. A more atrocious and blundering instance of ex post facto legislation than this can scarcely be pointed out. Here are three oaths, one described by the former statute; a second, which was taken by the Parliament at its prorogation; and a third contained in this last act of Parliament. All three oaths are different, and yet it is declared that the Parliament meant the second when they legislated concerning the first; that they meant the third when they took the second; and it is enacted that penalties imposed for not taking the first have been incurred by refusing to take the third. In this manner it was imagined that an appearance of legality was given to the confinement of Fisher and his fellow-prisoner. It seems probable, however, that the second oath was the one tendered to them, and if so the Statute after all left their case untouched.

We are indebted to the same wise Parliament which passed this Statute for many other legislative curiosities. Their first act $q$ declared that the King was the Supreme Head of the Church of England, and " for increase of virtue in Christ's religion " it was enacted that he should have "as well the title and style thereof," as all privileges "to the said dignity belonging."

The thirteenth act ${ }^{\mathrm{r}}$ of the same session enacted that if any person, after the tirst day of February next coming, should maliciously wish, will, or desire, by words or writing, or by craft imagine, invent, practise, or attempt, any bodily harm to the King, Queen, or heir-apparent, or to deprive them of the dignity, title, or name of their royal estates, every such person should be guilty of high treason. It is to the credit of the House of Commons that, pliant as they had hitherto shown themselves, they were in some degree roused by the proposition of this enactment. We learn from a document, which $I$ have given in the Appendix, ${ }^{\mathrm{s}}$ a fact which $I$ think has not hitherto been noticed, that "when this act was in hand in the Common House, because it was thought by divers of the said House that no man lightly might beware of the penaltie of the said Statute, therefore there was much sticking at the same in the Common House," and the act was not allowed to pass until it was added that the said words should be spoken "maliciously." 4 26 Henry VIII. rap. 1.

r Ibid. cap. 13.

$s$ Appendix, VI. 
The chicanery of the judges rendered the humanity of the Commons unavailable, by declaring when, upon the trials of Fisher and More, they came to construe the Statute, that the word "maliciously" was but a superfluous and void word, "for," said these sages, "if a man speak against the King's Supremacy by any manner of means, that speaking is to be understood and taken in law as maliciously." $t$ The infamy of this construction is aggravated a hundredfold by a knowledge of the intention of the Commons.

The 22d act " of this same Parliament is a second attainder against Fisher, passed without hearing him in his defence, and possibly even without his knowledge. It recites that the oath directed to be taken by the Statute of 25 Hen. VIII. c. 22 was tendered to Fisher since the 1st of May then last, and that he refused to take it, and enacts that he should be therefore attainted of misprision of treason, with forfeiture of his effects from the 1st day of March then last, and that the see of Rochester should be held vacant from the $2 \mathrm{~d}$ day of January then next.

Notwithstanding the wisdom of punishing an offence committed on the 1st of May by a forfeiture from the 1st of March preceding, this Statute certainly gave a legislative sanction to the imprisonment of Fisher, and by depriving him of his property and his Bishopric placed him altogether at the mercy of the Court. It might have been expected that the King would have been satisfied with his humiliation, the extinction of his political power, and his confinement during pleasure. But the anger of Henry VIII. was seldom appeased by anything but blood. If the misery of his victim could have sufficed, his satisfaction would in Fisher's case have been ample, for a more pitiable picture than is presented of his condition in a letter written to Cromwell a few days before Christmas 1534, can scarcely be imagined. Part of this letter was published by Strype, ${ }^{\mathbf{x}}$ and a further part of it may be found in Bayley's History of the Tower, ${ }^{y}$ and in the Biographia Brit. art. Fisher, but as all these publications are in some degree inaccurate, and the entire letter has not perhaps been published, I have placed it in the Appendix. ${ }^{\mathrm{z}}$

t Howell's State Trials, vol. i. p. 401.

x Strype's Cranmer, p. 13, Appendix.

z Appendix, IV. u Authentic edit. of the Stats. vol. iii. p. 52\%. y Bayley's Hist. Tower, vol. i. p. 136. 
Fisher was confined in the Tower for fourteen months, and received the severe treatment which was then the common lot of state prisoners. The Licutenant's charge for his maintenance was twenty shillings per week, ${ }^{\mathbf{a}}$ but the diet with which he was provided was, as he terms it, "so slender," that, having no means himself, his brother supplied the deficiency " out of his own purse," and " to his great hindrance." $\mathrm{b}$ About the commencement of 1535 his brother died, and then Fisher, being " in great need," was indebted to the bounty of his friends at Cambridge and elsewhere. The description which he gives ${ }^{c}$ of his ragged and rent clothes, which he says be would not have complained of if they would have protected him from the cold, has been often quoted. In the same letter he humbly entreated, but probably without success, to be allowed a priest to hear his confession, and also to be permitted to borrow some religious books. Bad as his treatment was, it does not seem to have been worse than ordinary; the charge for his board, indeed, however slenderly he was provided, was as much as that for any one of the prisoners mentioned in the paper from which I have obtained the information, and far more than for most of them, ${ }^{\mathrm{d}}$ and in other respects his usage was quite in keeping with that of More and the Duke of Norfolk, the latter of whom gave a description of his confinement in a paper to be found in Lord Herbert.e Fisher, however, was a man upon whom imprisonment was likely to produce its worst effects. His life had been one of constant and considerable occupation and activity, and a fondness for field sports, or at any event for coursing, is noticed amongst his peculiarities. ${ }^{f}$ The pleasures of the table were not much considered by him, but with a view to the preservation of health he had been accustomed to a spare and regular diet. "He never sat fully one hour to dinner." g In eating or drinking he limited himself to some precise quantities, which were measured and weighed out for him. He was punctual in taking his

a Cott. MSS. Titus, B. I. fol. 155.

b Appendix, IV.

c Ibid.

d The charge for the "bord-wages" of Sir Thomas More and his Servant was fifteen shillings per week, to pay which his wife states, in a letter to Cromwell, that she had been "compelled of verey necessyte to sell part of her apparell for lack of other substance to make money of." Howard's Collection of Letters, 4 to. 1753, p. 271.

e Herbert's Henry VIII. p. $566 . \quad$ f Harl. MS. No. 704\%, p. 207.

g Ibid. p. 16. 
meals at certain particular hours, so that in travelling from Rochester to London, "because the time of his refection was come, he took his dinner upon the top of Shooter's Hill, his servants standing round about him." h Doubtless these peculiar habits were little regarded during his confinement, and their interruption was certainly calculated to aggravate his maladies; at any event he was ill almost all the time he was in the Tower: and notwithstanding Henry, with a strange affectation of humanity, caused him to be attended by his own physician at an expense it is said of forty pounds, ${ }^{i}$ he was so weakly at the period of his execution as scarcely to be able to crawl from his prison in the Bell Tower to Tower Hill, so that a chair was carried at his side on which he rested thrice on the way. ${ }^{k}$

During his imprisonment he was permitted to receive a letter from his friend Erasmus ${ }^{1}$ after it had been inspected by Cromwell, and he also found means, through a servant of the Lieutenant of the Tower named George, to communicate with Sir Thomas More. It seems not unlikely that George was a mere spy, at any event the passing of these letters became known to the government, and excited considerable attention. They have also been lately alluded to by $\mathrm{Mr}$. Turner, ${ }^{\mathrm{m}}$ and made a groundwork of the theory by which he seeks to palliate the deaths of Fisher and More. More's statement of the contents of these letters given on his trial is already known, ${ }^{\mathrm{n}}$ and in one of the papers in my Appendix ${ }^{\circ}$ will be found Fisher's account of them upon oath. Between the two it pretty clearly appears how much treason they contained. They seem to have been mere letters of inquiry, each of them wishing to know the answers which the other had made to the council; Fisher, indeed, went a little further, and with a kindly feeling communicated to More the account he had heard of the insertion of the word "maliciously" in the Statute. The writing of these letters appears to have been made an article of charge against More, but as to Fisher I think I can show pretty clearly it was not so.

h Harl. MS. No. 7047, p. 17. Appendix, VI.

n Wordsworth's Eccles. Biog. vol. ii. p. 204. More's Life of More, Hunter's edit, p. 260. State i Ibid. p. $21 . \quad$ k Ibid. p. 15 b.

m Hist. of Henry VIII. vol. ii. p. 38\%, 390 .

- Appendix, VI. 
For the credit of St. John's College, Cambridge, it ought not to be unnoticed, that in this time of danger they were mindful of the benefits Fisher had conferred upon them. During his imprisonment the Master and some of the Fellows are said to have waited upon him several times, and Baker, the Cambridge Antiquary, tells us that "several things" are entered upon the College Books for his use and service.p There is also amongst the Baker MSS. a cop! q of what Baker very justly terms "a noble letter" transmitted to Fisher by the College, in which, after acknowledging that they were indebted to him for maintenance, for learning, and for every good they possessed or knew, they besought him to use whatever they had as his own, and proceeded in a strain of strong and highly honourable feeling: "Tuum est eritque quicquid possumus. Tui omnes sumus erimusque toti. Tu nostrum es 'decus e t presidium,' tu nostrum es caput ut necessario quæcunque te mala attingant ea nobis veluti membris subjectis acerbitatem inferant."

I now arrive at the concluding and most important portion of my subject. By the Act of 25 th Henry VIII. cap. 12, Fisher was attainted of misprision of treason, and subjected to a forfeiture of his personal estate, and imprisonment for life, for his concealment of Elizabeth Barton's prophecies; on the 13th April 1534 he was committed to custody for refusing to take the oath to the succession tendered to him at Lambeth; on the 17th of April, upon a repetition of his refusal, he was committed to the Tower; and by the 26 th of Henry VIII. cap. 22, his refusal was punished by a second attainder of misprision of treason and a deprival of his bishopric. Hitherto the proceedings against him had not affected his life; we are now to consider what was the subsequent crime which brought to the scaffold an old man already bowed down by infirmities, a prisoner for life, stripped of his property, and deprived of the episcopal dignity, which gave him consideration in the State, and an opportunity of opposing the measures of the Court in the House of Lords.

During Fisher's confinement in the Tower he was visited several times by 
the Lords of the Council. Their first visit occurred after he had been but a few weeks in the Tower, and was made apparently for the purpose of giving him an opportunity of recanting his refusal to take the oath to the succession. I imagine this visit to have taken place about the 1st of May 1534, the day after which, according to the second act of attainder against him, the oath to the succession was tendered to him for the last time. In the interval between this and their next visit, which occurred on the 30th of April 1535, there had been the session of Parliament of the 26th of Henry VIII. during which were passed the statute which conferred upon Henry the title of Supreme Head of the Church, and that "which made words treason." Upon their second visit, we are told, the Lords of the Council "were sent to know his opinion touching the Statute of Supreme Head;" a sending which, it is not unimportant to remark, was entirely gratuitous, inasmuch as nothing in any act of Parliament authorised the Lords of the Council to inquire into the opinions of any one upon that subject. It seems that when these Lords began to interrogate Fisher as to the Supremacy, he, having heard "the act which made words treason" read over "once or twice," by his servant Wilson, immediately suspected that they had come for the purpose of entrapping him into some avowal which might be the occasion of further trouble to him. With that view he told them, that " the Statute did not compel any man to answer, and besought that he should not be constrained to make further or other answer than the Statute did bind him to make." A few days afterwards the Council were a third time at the Tower, and probably he was a second time interrogated with respect to his opinion upon the Statute of Supreme Head. I infer this from the circumstance, that Sir Thomas More, who was examined as well as Fisher upon the previous days, was examined a third time about the 4th of May 1535. Upon all these occasions both Fisher and More declined giving any opinion as to the Supremacy, and Fisher imagined that by this course he should escape the snare laid for him. On the $2 \mathrm{~d}$ of June 1535, however, a special commission was issued for his trial on a charge of high treason. After the issuing of the commission, on the 12th of June, and again on the 14th, he was visited by some of the members of the Council, and subjected to further examinations upon interrogatories. The proceedings upon the 
19th of June are to be found in the Appendix ; $^{\mathrm{r}}$ those on the 14th may be seen in the volume of State Papers lately published.s On both these days he guardedly maintained his determination to abstain from answering any questions whereby, as he expressed it, " he might fall into the dangers of the Statutes." $t$ His conduct on these occasions would seem to intimate that he was ignorant of the manner in which he had already made himself amenable to the Statutes, and of the determination to try him. The real objects of these last two examinations are not clear to me, but such inquisitorial proceedings were so totally opposed to the spirit of the English Law, that it is scarcely possible to reason with certainty concerning them; every step in these proceedings led their originators further from the forms as well as from the substance of justice. I can only suppose that these examinations were had recourse to for one of the following reasons; either to give Fisher a final chance of escape by submission; or to get from him some evidence to confirm the testimony against him; or to obtain information which might be used as evidence against others. It is not improbable that the portion of his examination, which related to the letters which passed between Sir Thomas More and himself, was used against Sir Thomas on his trial.

In the course of three days after his last examination he was placed upon his trial ; found guilty of treason; and was executed on the 22d of June 1.535. This extraordinary proceeding against a man already deprived of every thing but life, was apparently one of such gratuitous cruelty, that, in

r Appendix, No. VI. This document is copied from the original in the handwriting of John Ap Rice, the notary who was present at the examination. It is signed by Fisher at the bottom of every page, and it will be remarked that he still used his episcopal title, although by the Act of the 26th Henry VIII. cap. 2\%, he had been deprived of his see from the $2 \mathrm{~d}$ of January preceding. This examination is a document of some interest, and will be found to be my authority for many of the facts I have stated. Annexed to one of Fisher's Letters (Cleopatra, E. vi. p. 172) is a series of answers to annther set of interrogatories, all written by the Bishop himself in Latin. They seem to have reference chiefly to the authorship of some works respecting the divorce; the handwritin:, however, is to me so nearly illegible, that $I$ have been able to acquire but a scanty knowledge of their contents. In early life Fisher was noted for the neatness of his writing, and some of his later letters are intelligible enough ; but this document was written, I suppose, during his sickness and imprisonment, which may account for its illegibility.
s P. 431.
t Ibid. p. 432. 
the absence of all documents respecting the trial, and all authentic information as to the evidence against him, historians, who hold themselves bound to explain every thing, have suggested various reasons for its adoption. Those of the older authors, who trouble themselves with the causes of events, state distinctly, that Fisher's crime consisted in the denial of the supremacy, but without informing us how or when that denial took place. Dir. Baily, or rather Dr. Hall, is the only one who gives any thing like a detailed account of the transaction; and his violent partizanship has thrown a doubt around every thing he wrote. In his Life of Fisher he relates, that the Lords of the Council, having determined to release him from his "cold and painful imprisonment," and yet finding themselves unable to draw from him any opinion upon which to found a new accusation, employed Mr. Robert Rich, then lately Solicitor-general, and afterwards Lord Chancellor, to inveigle him into a conversation upon the subject of the Supremacy, under pretence that he was sent privately by the King, and for his especial information. The Bishop, or rather Dr. Fisher, for he was a Bishop no longer, could baffle a direct question, but was not proof against artifice. $\mathrm{He}$ incautiously declared that, in his opinion, the King, as a layman, neither was, nor rightfully could be, the Head of the Church; and for this avowal thus made, and, according to the statement of Dr. Hall, for no other cause, Fisher was brought to the scaffold upon the evidence of Rich. Hall's Life of Fisher is undoubtedly a book of no very great authority, and without some confirmatory testimony is not conclusive upon any point. I think, in this instance, Dr. Hall's authority may be corroborated by a good deal of collateral evidence, and that his book does not therefore deserve to be so entirely disregarded as it has been by some later authors. It seems clear that Rich was at the Tower about the day on which this conversation is stated to have taken place, being at that time sent to take away Sir Thomas More's books from him.u The infamy of the conduct imputed to Rich does not afford any sufficient reason for supposing him incapable of it; he was a man of bad

u Roper, p. so. Roper does not mention the precise day ; but it is clear that it was immediately after the second visit of the Lords of the Council to examine Fisher and More as to the Supremacy ; and that appears, from Letters XI. and XII. in Roper's Appendix, to have been two or three days after the 4 th of May. 
character, and it is indisputable that a fraud of the same description was practised against Sir Thomas More by this very Rich, upon the occasion of this very same visit to the Tower. Again, the account is supported as to the words alleged to have been used, by the only document relative to the trial known to exist, and also by Lord Herbert. There is nothing certainly known from which we may infer whether Rich was employed by the Government to entrap Fisher and More, or not; it is not unlikely, that being sent to the Tower by the Council to take away More's books, he entered into conversation with both the prisoners, and afterwards communicated to the Council their confidential disclosures-if, indeed, More used the words attributed to him by Rich, which is very doubtful. The Council took advantage of Rich's baseness, and may therefore, with very little injustice, be suspected of having prompted it.

Some modern authors, who have written with a friendly feeling towards Henry, relying upon the absence of the documents relating to Fisher's trial, and choosing to disregard Dr. Hall's statement, have inferred that there must have existed some other reason for Fisher's "hard measure," than " the mere theoretical refusal to acknowledge the ecclesiastical chieftainship," $x$ and that he and More must have suffered upon accusations and convictions, of being abettors or participators in treasonable conspiracies. In support of these conjectures, advantage has been taken of a phrase of Lord Herbert's, that Fisher was put upon his trial "for divers points;"y but without sufficiently noticing that his Lordship, as if desirous that no one should build a theory upon his words, honestly adds, " the particulars of which I have not seen, but only that on the 7th of May last, in the Tower of London, before divers persons, he had falsely, maliciously, and traitorously said, "the King is not Supreme Head of the Church of England." In alluding to the " divers points," Lord Herbert was therefore merely repeating the common rumour upon the subject; a rumour contradicted by the only document to which he had access.

Upon this point I am desirous of drawing attention to a MS. which is probably the very document Lord Herbert saw, but which since his time

x 'Turner's Henry VIII. vol. ii. p. 387, 2d. edit.

y Lord Herbert, p. 392. 
has not been sufficiently noticed. It occurs amongst the Cotton MSS. and is described in the Catalogue as "a censure of Bishop Fisher for not acknowledging the King's Supremacy;" but is in fact a copy of all the important part of his indictment ; that part, namely, which charges the criminal conduct for which he was put upon his trial. It is written in the old Court hand, and seems as if it had been fairly copied from the indictment itself, by some person sufficiently acquainted with the nature of such a proceeding, to be able to extract merely its sum and substance, unburthened by the recitals of the acts of 26 Henry VIII. cap. 1, and 26 Henry VIII. cap. 13 . These statutes were evidently contained in the original, and must have made it, what it is described to have been, "very long, and full of words." The only offence here charged is, that of having, in the Tower of London, on the 7th of May 1535, spoken the following words: "The King, our Sovereign Lord, is not Supreme Head in Earth of the Church of England." In stating the offence which the speaking of these words constituted, all the verbiage of the Statute of 26 Henry VIII. cap. 13, is employed, and the crime is alleged to consist in their evidencing that the prisoner "falsely, maliciously, and traitorously wished, willed, and desired, and by craft imagined, invented, practised, and attempted, to deprive the King of the dignity, title, and name of his royal Estate, viz. of his dignity, title, and name of Supreme Head of the Church."

If this document is what I have described and believe it to be, the question, as to the legal crime for which Fisher suffered death, may be considered settled. Disgraceful as the fact is, I cannot see how we can escape from the persuasion, that the mere denial of the Supremacy, into which he was probably inveigled, and not any participation in treasonable plots or conspiracies, was the legal pretence for Fisher's execution. The document referred to is printed in the Appendix. ${ }^{z}$

The act of Parliament upon which this indictment was principally founded, is certainly of a most atrocious character, and evidences a state of society but little removed from actual barbarism; but the construction, by which the mere expression of an opinion upon a disputed point in theology,

2 No. V. 
was held to amount to a malicious and treasonable attempt to deprive the King of his title of Supreme Head, is, if possible, even more iniquitous than the Statute itself. Every principle of legislation was violated by the lawmakers, who created a treason out of men's wishes and desires, and not less violence was done to all rules of construction, by stretching the latitude of this highly penal Statute, so that not merely wishes and desires, but even opinions were comprehended within its fatal enactments. Every thing relating to the criminal proceedings of this period was so irregular; humanity and even honesty were so frequently absent from the judicial seats; the inAuence of the Monarch was so openly thrown into the scale by Judges who were the mere delegates of his vindictive spirit; there was so much anxiety to obtain a conviction, at whatever cost and by whatever means-that those who infer that Fisher could not have been convicted for the mere utterance of an opinion, because such a conviction would have been tyrannical and unjust, shew, I fear, a disposition to judge of the legal proceedings of the reign of Henry VIII. by the example of our own times, rather than by that which they themselves exhibit.

Many collateral arguments might be adduced in support of the authenticity of this extract from Fisher's indictment, but I will merely remark the confirmation it receives from another document in the same volume of Cotton MSS. ${ }^{a}$ This is a parchment erroneously described in the Catalogue as " a bill found against Bishop Fisher and James Whalworth for denying the King's Supremacy." It has in truth no other connection with Bishop Fisher than this, that it is a true bill found by a Grand Jury against John Rochester and James Whalworth, Carthusian Monks, for the very identical offence which, in the extract from the indictment against Fisher, is made the subject of charge against him. The denial of the Supremacy, and that alone, was the charge against these Monks, and if an extract were taken from their indictment of the part corresponding with the portion contained in the extract from Fisher's, the two would be found to agree in every essential particular. It is futile then to contend that there must have been other charges against Fisher, because " the single act of not acknow- 
ledging the King's Supremacy was not high treason."b The "not acknowledging" the Supremacy was not the charge against Fisher; but we have seen in what manner the expression of an opinion against the Supremacy could be distorted into high treason, and we here find a complete indictment for the very same offence, and in which this very denial constitutes the only charge. Upon the trial of More the doctrine was actually carried to the extent denied to be law by Mr. Turner; for in his indictment it was one of the charges against him from which treason was to be inferred, that, when interrogated respecting the Supremacy, " he maliciously held his tongue." c

A reason for the harsh proceedings against Fisher, which has been very commonly insisted upon, is that his injudicious appointment by the Pope to the dignity of the purple, "alarmed the government" and awakened the sleeping vengeance of the King, who instantly determined to put him upon his trial. Fisher's appointment as Cardinal took place on the 21st of May, ${ }^{d}$ and the commission to try him was dated on the $2 \mathrm{~d}$ of June, ${ }^{\mathrm{e}}$ before the news of the appointment at Rome could have been received in London. This seems to prove that the determination to bring him to trial must have preceded his appointment. Indeed, no one who considers the manner in which he was first tempted by the Council, and afterwards betrayed by Rich, into the declaration which was fatal to him, can think that it had not for some time been determined to put him upon his trial. Whether the appointment did not hasten his execution is another question upon which some persons may doubt. In Fisher's instance I can find nothing but what seems to mark a leisurely proceeding in a settled and determined course. His appointment to the purple was on the 21st of May, the commission to try him was on the $2 \mathrm{~d}$ of June, the news of his appointment reached London several days before the 12 th of June, ${ }^{f}$ but he was not tried until the 17 th, and then, to the general surprise, five days elapsed before the order arrived for his execution. I cannot here trace the hurry of alarm which some writers have imagined. Such transactions were often dispatched in

b Turner's Henry VIII vol. ii. p. 387; 2d edition.

c Herbert, p. 393.

d Wharton's Anglia Sac, vol. i. p. 383.

e Harl. MS. No. 7047, p. 21.

f It was known before the date of the document VI. in the Appendix. 
the reign of Henry VIII. in a far shorter time, and would have been got through more quickly in Fisher's instance, if the arrival of the Cardinal's hat in England in time to be placed upon its owner's living head, had been a subject of alarm. Indeed, if it can be considered settled that the determination to put him upon his trial, or in other words, if the desire to get rid of him, existed before the English Court were aware he had been appointed a Cardinal, the other question is of minor importance, since it would have been a solecism in the unrelenting character of Henry VIII. if he had paused between the wish to destroy and its accomplishment.

There are various statements of the feelings with which Fisher himself riewed his appointment; but there can be no reason to doubt his own account upon oath, which will be found in the Appendix, ${ }^{\mathrm{f}}$ that when the news was told him he declared "that if the Cardinal's hat were layed at his feet he would not stoop to take it up, he did set so little hv it" .

The harsh treatment of Fisher does not seem to have terminated with his existence. If the Roman Catholic writers are to be credited, his lifeless body was treated with most scandalous indignity. Much of Dr. Hall's account of this transaction is told in a very simple and credible manner; but, for the sake of humanity, it is to be hoped that other portions of his narrative partake largely of that spirit of romance which may be traced throughout his work. Hall, the chronicler, records merely that Fisher was be-

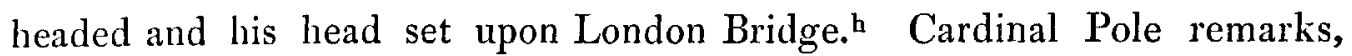
that the lifeless body was treated with every description of contumely, and, by direction of the King, was exposed entirely naked at the place of execution as a sight for the rabble to gaze at. He adds that so great was the popular dread of Henry, that no one approached the body except those who came for the sake of treating it with indignity, and the persons who stripped it of its clothes. ${ }^{i}$ This is sufficiently horrible; but Dr. Hall's minute account is still more so. "Then," he says, "the executioner stripping the body of his shirt and all his clothes, he departed thence, leaving the headless carcase naked upon the scaffold, where it remained after that sort for the most part of that day, saving that one, for pity and humanity sake, cast a little straw over it; and about eight of the clock in the evening, com-
g Appendix VI.
h p. 817, edit. 1809.
i Poli Apolog. ad Carolum, p. 96. 
mandment came from the King's Commissioners to such as watched about the dead body (for it was still watched with many halberds and weapons) that they should cause it to be buried. Whereupon two of the watchers took it upon a halberd between them, and so carried it to a churchyard there hard by, called All Hallows Barkin, where, on the northside of the churchyard, hard by the wall, they digged a grave with their halberds, and therein without any reverence tumbled the body of this holy prelate, all naked and flat upon his belly, without either shirt or other accustomed thing belonging to a Christian man's burial, and so covered it quickly with earth." $\mathbf{k}$ I fear it is but too probable that some indignities were practised; but I doubt whether Hall's account is any thing more than a mere imaginary amplification of the statement of Pole, whose warm feelings probably led him into some exaggeration. Such excessive and disgusting cruelty is almost incredible ; and "seeing," as Fuller remarks," " the King vouchsafed him the Tower-a noble prison, and beheading - an honourable death, it is improbable he should deny him a necessary equipage for a plain and private burial." It is certain that the corpse was first interred in the churchyard of All Hallows Barking, and afterwards, but at what distance of time does not appear, removed to the chapel of St. Peter ad Vincula in the Tower, and deposited there, near the remains of Sir Thomas More. If Hall's account were true, the body would soon have been in such a state of decomposition as to render a removal scarcely possible-at any event he does not appear to have been aware of the removal, for he remarks that it was observed by foreigners resident in London, that for seven years " there grew neither leaf nor grass upon his grave, but the earth still remained as bare as though it had been constantly occupied and trodden." ${ }^{n}$ If Hall had known that the removal took place within seven years, he probably might have thought it proper to abridge the duration of this miracle.

After an exposure of fourteen days upon London Bridge, the head was taken down and thrown into the Thames, in consequence of " a report," says Dodd, " that rays of light were observed to shive around it." I know not where Dodd obtained his account of the rays of light ; Hall merely says,

k Life of Fisher, p. $210 . \quad 1$ Fuller's Church History, p. 205.

$\mathrm{m}$ Newcourt's Repertorium, vol. i. p. 529. $\quad \mathrm{n}$ Life of Fisher, p. 213.

- Dodd's Church History, vol. i. p. 161. 


\section{s. Circumstances attending the Death of Bishop Fisher.}

that the face was observed to become "fresher and more comely day by day," and that such was the concourse of people who assembled to look at it, that " almost neither cart nor horse could pass."

Such are the particulars which $I$ have been able to glean respecting Bishop Fisher. The subject will be thought by many not to be of sufficient interest to merit so much attention. It seems to me that every particular relative to a condemnation so iniquitous as Fisher's, deserves to be accurately known, and although Henry VIII. strove to obliterate him from the general recollection by prohibiting the perusal of his works, $q$ and effacing his arms which were carved upon the stalls in the Chapel of St. John's, and upon a tomb he had there prepared for himself, $r$ we ought to pay the justice to his memory which was then refused. It is a shame to our biographers that there does not at this time exist a life of Bishop Fisher of any value or authority. Dr. Fiddes, Lewis the biographer of Caxton, and Mr. Alban Butler, were all engaged upon the subjct, but without any profitable result. Of Fiddes's collections I know nothing, he had the loan of the Baker MSS. which I have consulted; Mr. Lewis's work was some time since in the hands of the Rev. Theodore Williams; and Mr. Alban Butler's collections were in the possession of Mr. Charles Butler, but have been destroyed. In the meantime Dr. Bailey's, or rather Dr. Hall's Life of Fisher, printed in 1655, and now seldom met with, is the only book upon the subject. I have abstained as much as possible from having recourse to Hall's work, because I was desirous of ascertaining how much might be gathered from other sources either to corroborate or contradict his statements. The result is in most instances favourable to his correctness, although many things in his volume are clearly fabulous. His account of the trial and execution of Fisher, which is copied into our State Trials, appears to me to be written in a style so plain and simple, and with such an air of truth, that if considered merely as a composition it ought to render the book of considerable value.

I am, my dear Sir, your very faithful, humble servant,

Thомas Anyot, Esq. \&c \&c. \&c.

JOHN BRUCE,

P Life of Fisher, p. $212 . \quad$ i Cott. MS. Titus, B. I. fol. 535. r Harl. MS. No. 7047, p. 16 b. 


\section{APPENDIX OF DOCUMENTS.}

No. I.

Cott. MSS. Vespasian, F. xir. fol. 154 b.

Master Cromwell, after my right humble comendations I beseiche you to have some pytye of me, considry'g the case and condition that I ame in; and I dowt not but yf ye myght see in what plyte that I ame ye woulde have some pyte uppon me, for in goodfaythe now almoste this six weekys I have hadde a grevous cowighe $\mathrm{w}^{\mathrm{t}}$ a fever in the bigynnynge thereof, as dyvers other heare in this countre hathe hadde, and dyvers have dyed thereof. And now the mattyer is fallen downe in to my leggis and feit, $w^{t}$ suche swellinge and aiche that I maye nother ryde nor goo, for the whiche I beseiche you eftsonys to have some pyte uppon me and to spare me for a season, to thene the swellinge and aiche of my leggis and feit maye swaige and abait, and then by the grace of $o^{r}$ Lorde I shall $w^{t}$ all speide obeye $\mathrm{yo}^{\mathrm{r}}$ comaundement. Thus fare ye weall, at Rochestre the xxviij daye of Januarij,

By yor faythefull Beadman, Jo. Roffs.

No. II.

Cott. MSS. Cleopatra, E. vi. fol. 161.

Aftir my right humble comendations I most intierly beseche you that I no farther be moved to mak awnswere unto $\mathrm{yo}^{\mathrm{r}}$ letters, for I se that myn awnswere most rather growe in to a greate booke or els be insufficient, so that ye shall still thereby tak occasion to be offendid, and I nothing proffitt. For I perceyve that every thinge that I writte is ascrybed either to craft, or to willfullnes, or to affection, or to unkyndnes agaynst my soveraigne, so that my writinge rather provokithe you to displeasur than it forderithe me in any poynt concernyng yor favor, whiche I most affectually coveyte. Nothinge vol. $\mathrm{xxV}$. 
I redd in all your longe letters that I tak eny comfort of but the oonely subscription, wher in it pleaside you to call you my frende, whiche undoubtydly was a worde of moche consolation unto me, and therefor I beseeche you so to contynew, and so to shew yorself unto me at this tyme. In ij poyntes of my writinge me thought ye were most offendide, and boithe concernyd the Kinges grace. That oone was where I excusyd my self by the displeasur that his highnes tok $w^{t}$ me when I spake oons or twyse untill hyme of lyk matters. That other was where I towchide his great mattier. And as to the furst, me think it veary harde that I myght not signyfye unto you suche things secreatly as myght be most affectuall for myn excuse; and as to the seconde my study and purpose was specially to declyne that I shoulde not be straytede to offende his grace in that behalf, for thene I most nedis declare my conscyence, the whiche as thane I wrote I wulde be lothe to doo any more largely than I have doone; not that I condeme any other menys conscyence, there conscyence maye save theme, and myne must save me. Wherefor, good master Cromewell, I beseche you, for the love of God, be contented $w^{t}$ this myne awnswere, and to give creadence unto my brother in suche thingis as he bathe to saye unto you. Thus fare ye weeale, at Rochestre the $x x x j$ daye of Januarij, by yor faithefull Beadman,

Jo. Roffs.

No. III.

Cott. MSS. Cleopatra, E. vi. fol. 162.

Please it yor most graciouse hyghenes benignely to heare this my most humble sute which I have to make unto yor grace att this tyme, and to pardone me that I come nott myself unto yor grace for the same, for in good faith I have hadde so meny periculouse diseases oone after an other, which beganne with me before Advent, and so by long continuaunce hath now brought my bodie in that weakenesse that withouten perill of destruction of the same, which I darr saye yor grace for $\mathrm{yo}^{\mathrm{r}}$ soveraigne goodnes wold not, I maye not as yett take any travayling upon me; and soo I wrote to Maister Cromewell, yor most trustie counsaillor, besechying him to obtayne $y o^{r}$ graciouse licence for me to be absent from this pliament for that same cause, and he putt me in comforthe soo to doo. Now thus it is, most 
graciouse Soveraigne Lorde, that in yo ${ }^{r}$ moost highe Court of Parliament is put in a bill agaynest me concernyng the Nuñe of Cantrburye, and intendyinge my condempnation for not revelyng of such wordes as she hadde unto me towchyng yor highnes, wherein I most humblie beseche youre grace that withowten your displeaso ${ }^{r}$ I maye shewe unto yow the consideration that moved me soo to doo, whiche when youre moost excellente wisdome hath deaplye considered I trust assuredly that $\mathrm{yo}^{\mathrm{r}}$ charitable goodnes will not impute any blame to me therefore.

A trowth it is this Nuñe was [with] me thries in comyng from London by Rochester, as I wrote to maister Cromwell, and shewed unto hym the occasions of her cor̃yng and of my sendynges untill her agayne.

The first time she came unto my howse, unsent for of my partye, and than she told me that she hadde bene with yor $^{\mathrm{r}}$ grace, and that she had shewed unto yow a Revelation whiche she hadde from Allmighty God; yor grace I trust will not be displeased with this my rehearsall therof. She said that if $y^{r}{ }^{r}$ grace went forth with the purpose that ye entended, ye should not be Kynge of Englande vij monethes after.

I conceaved not by theis wordes, I take it upon my sowle, that any malice or evill was entended or ment unto yor highenes by any mortall man, butt oonly that thei were the threattes of God, as she then did afferme.

And thoughe thei were feaned, that (as I wold be saved) was to me unknowen. I neṽ counsailled her unto that feanynge, nor was pryvaye thereunto, nor to any such purposes as it now is sayd thei went abowte.

Neverthelesse, if she hadde told me this Revelation, and hadde not alsoo tolde me that she hadde reported the same unto youre grace, I had bene verylie farre to blame and worthy extreame punyshement, for not disclosyng the same unto your highenes or elles to some of $\mathrm{yo}^{\mathrm{r}}$ Counsaill. But sithen she did assure me therwith that she hadde playnelye told unto yor grace the same thynge, I thought dowtlesse that your grace wold have suspected me that I hadde comyn to renewe her tale agayne unto you, rather for the cõfyrmyng of myn opinion than for any other cause.

I beseche yor highnes to take no displeasor with me for this that I will saye. It stykketh yet, moost graciouse Soveraigne Lorde, in my hart to my no little hevynesse, youre greviouse Ires, and after that yor moche fearfull 
wordes, that $\mathrm{yo}^{\mathrm{r}}$ grace hadde unto me for shewyng unto yow my mynde and opinion in the same matter, notwithstandyng that $\mathrm{yo}^{\mathrm{r}}$ highenes hadde soo often and soo straytly comanded me to serch for the same before, and for this cause I was right loth to have com̃yn unto your grace agayne with such a tale ptaynyng to that matter.

Meny other considerations I hadde, but this was the very cause why that I came not unto $\mathrm{yo}^{\mathrm{r}}$ grace; for in good faithe I dradde lest I shold therby have provoked $\mathrm{yo}^{\mathrm{r}}$ grace to farther displeaso ${ }^{\mathrm{r}}$ agaynst me.

My lorde of Cantrbury also, which was yo $^{r}$ greate Counsaillor, told me that she hadde bene with $\mathrm{yo}^{\mathrm{r}}$ grace and hadde shewed yow this same matter, and of hym (as I will answere before God) I learned greatter thynges of hir ptensed visions than she tolde me hirself. And at that tyme I shewede unto hym that she hadde bene with me and told me as $I$ have writen before.

I trust now that $\mathrm{y}^{\mathrm{r}}$ excellent wisdome and learnynge seeth ther is in me no defawte for not revelynge of her wordes unto yo $^{r}$ grace, when she herself did affirme unto me that she hadde soo done, and my Lord of Cantrbury that then was, côfermed also the same.

Wherfore, most graciouse Soveraigne Lorde, in my most humblie wise, I besech $y 0^{r}$ highnes to dimisse me of this trooble, wherby I shall the more quietly serve God and the more effectuelly pray for $y o^{r}$ grace.

This if ther were a right greate offense in me shold be to yor merite to pardon, butt moch rather takyng the case as it is I trust verily ye will soo doo. Now my body is moch weakened with meny diseases and infirmities, and my sowle is moch inquieted by this trooble, so that my harte is more withdrawen from God and fro the devotion of prayer than I wold. And veryly I thinke that my lyve maye not long côtenue; wherefor ${ }^{\mathrm{r}}$ eftsoones I besech yor moost graciouse highnes that by yo $^{r}$ charytable goodnes I maye be delived of this besynesse, and onely to pupaire my sowle to God and to make itt ready agaynest the comyng of death and no moore to come abroode in the worlde. This, mooste graciouse Soveraigne Lorde, I beseche $\mathrm{yo}^{\mathrm{r}}$ lighnes by all the singuler and excellent endowementes of yor most noble bodie and sowle, and for the love of Christ Jhũ, that soo dearly with his

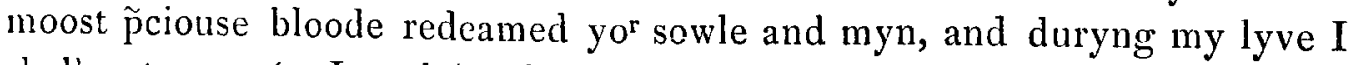
shall not cease (as I am bownden), and yet now the more entearly, to make 
occasioned the death of Fisher, Bishop of Rochester.

my prayer to God for the p̃servation of $\mathrm{yo}^{\mathrm{r}}$ most royal Majestie. Att Rochester the xxvijth daye of Februar.

Yor most hum̂il beadman and subject, Jo. Roffs.

No. IV.

Cott. MSS. Cleopatra, E. vi. fol. 172.-Autograph.

After my most humbyl comendacions, wher ass ye be content that I shold wryte unto the Kings hyghness, in gude fathe I dread me that I kan not be soo circonspect in my wryteng but that sume worde shal escape me wher with his grace shal be moved to sum farther displeasure againste me, whereof I wold be veray sorry; for ass I wyll answer byfor God, I wold not in any maner of poynt offend his grace, my deuty saved unto God, whom I muste in every thyng prefer; and for this consideracion $\mathrm{I}$ am full loth and full of fear to wryte unto his hyghnes in this matter. Nevertheless, sythen I conceyve that itt is $\mathrm{yo}^{\mathrm{r}}$ mynde that I shal so doo, I wyl endeavor me to the best that I kan.

But first hear I must beseche you, gode $\mathrm{M}^{\mathrm{r}}$. Secretary, to call to $\mathrm{yo}^{\mathrm{r}}$ rememberance that att my last beyng befor yow and the other Comyssionars for takyng of the othe cõcernyng the Kyngs most noble succession, I was content to be sworn unto that parcell côcernyng the succession; and there I did rehears this reason which $\mathrm{I}$ sade moved me, I dowted nott but that the prynce of eny realme, with the assent of his nobles and comons, myght appoynte for his succession Royal such an order ass was seen unto his wysdom most accordyng; and for this reason I sade that $I$ was content to be sworn unto that part of the othe ass concernyng the succession. This is a veray trowth, ass God help my sowl att my most neede. All be itt I refused to swear to sum other parcels, bycause that my conscience wold not serve me so to doo.

Forthermo ${ }^{r} \mathrm{I}$ byseche yow to be gode $\mathrm{M}^{\mathrm{r}}$. unto me in my necessite, for $\mathrm{I}$ have nather shert nor shete nor yett other clothes that ar necessary for me to wear but that be ragged and rent to shamefully. Nothwithstandyng I myght easyly suffer that if thei wold keep my body warm. Butt my dyet 
allso God knows how sclendar itt is att meny tymes. And now in myn age my sthomak may not awaye but with a few kynd of meatts, which if I want I decare forthwith, and fall in to coafes and disseasis of my bodye, and kan not keep myself in health.

And ass $o^{r}$ Lord knoweth, I have no thyng laft unto me for to provyde eny better, but ass my brother of his own purs layeth out for me to his great hynderance.

Wherfore, gode Mr. Secretarye, eftsones I bysech yow to have sum pittie uppon me, and latt me have such thyngs ass ar necessary for me in myn age, and specially for my health. And allso that itt may pleas you by yor hygh "yrdom to move the Kyng's hyghness to take me unto his graciouss favor agsane, and to restoor me unto my lyberty owt of this cold and paynefull cmprysonment, whearby ye shall bynd me to be yor pore beadsman for ever unto Alimyghty God, who ever have yow in his protection and custody.

Other twayne thyngs I must all so desyer uppon yow ; thattoon is that it may pleas yow that I may take sum preest with in the Tower by the assyment of $\mathrm{Mr}$ Levetenant, to hear my confession againste this hooly tyme; that other is that I may borow sum books to styr my devotion mor effectraily thes hooly dayes for the comforth of my sowl. This I beseche yow to grant me of yor charitie, and thus $o^{r}$ Lord send you a mery Chrystenmass ant a comforthable to $y^{r}$ harts desyer. At the Tower the xxii day of Dicember,

Yor pore beadsman,

Jo. Roffs.

No. V.

Cott. MSS. Cleopatra, E. vi. fol. 178 b.

Quid̄̃ tamen Johẽs Fyssher nup de Civitate Roffens. in Com. Kanc. Cłicus alias dñs Johẽs Fyssher nup de Rofeñ Epũs, Deum pre oculis non hens sed instigatione drabolica seductus, false maliciose et proditorie optans volens et desiderans ac arte imaginans inventans practicans et attemptans serenissimũ dũm nîm Henricum octavū, Dei grã Anglĩ et Ffranc. Regem Fidei Defensorem et Dnũ Hiøn. atqz in terra supremũ caput Ecctie Angli- 
canæ, de dignitate titulo et nõie status sui Regalis, videtit de dignitate titulo et nõie suis in tra sup̃ ma Capitis Anglicanæ Ecctie, đte imperiali Corone sue ut prmittr annexis et vinctis, deprivare, septimo die.Maii Anno regni ejusdem Dñi Regis vicessimo septimo apud Turrim London. in Com. Midd. contra legiancie sue debitũ hec ṽba Anglicana sequen. diṽsis dc̃i Dñi Regis veris subditis, false maliciose et proditorie loquebatr et ppalabat, videtit, "The Kyng owre Soṽaign Lord is not sup̃me hedd yn erthe of the Cherche of Englande," in đti đni Regis injuriũ despect. et vilipendiũ manifestũ ac in đtor. dignitatis tit̂li et nôis status sui regalis derogacoẽm

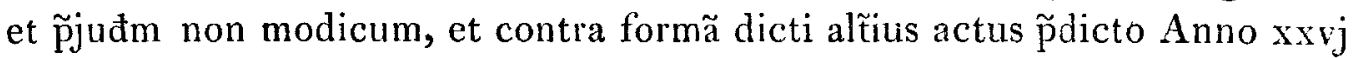
edit. et p̃iũs ac contra pacem p̃fati dñi Regis, etc.

No. VI.

Cott. MSS. Cleopatra, E. vi. fol. 169.

The Answeres made by $\mathrm{M}^{\mathrm{r}}$. John Fissher, Docto ${ }^{\mathrm{r}}$ of Divinitie, to the Interrogatorys mñstered unto hym the $x \mathrm{ij}^{\text {th }}$ daye of June, $\mathrm{a}^{\circ} \cdot \mathrm{r}^{\mathrm{i}}$. h. viii. $\mathrm{xxvil}^{\circ}$, within the Towre of London. Examined thereupon by $\mathrm{Mr}$. Thomas Bedyll and $\mathrm{M}^{\mathrm{r}}$. Richard Layton, clerke of the Kings Counsaill, in the psence of $\mathrm{Sr}^{r}$ Edmonde Walsynghĩ, knyght, Lieutenant of the said Towre, Henry Polstede, John Whalley, and me John ap Rice, Notarie underwriter, and sworne in ṽbo sacerdotis, that be wolde truly answere to the said Interrogatories, and to every pte of the same, as ferre as he knoweth or remẽbreth.

To the first Interrogatorie he saith, That whan thacte by the which wordes are made Treason was a making, Robert Fissher his brother came to hym to the Towre, and said that there was an acte in hande in the coñon house by the which speking of certain words against the kyng shulde be made treason; and because it was thought by divers of the said house, that no man lightly coulde beware of the penaltie of the said statute, therefor there was moche sticking at the same in the coên house; and unlesse there were added in the same that the said wordes sholde be spoken maliciouslie, he thought the same shulde not passe. And then this rñdent asked bỹ whether men shulde. 
be bounde to make any answere to any poynte upon an othe by the vertue of the same acte, like as they were by the tother acte of Succession. And he said nae. And no other coñation had this depot with hym to hys rem̃berance at any time touching the said acts or any of theym.

To the second Interrogatorie he hath answered afore, and no other answere can he make to the same, as he saith.

To the iijth, he dothe not remẽbre that ever he had such coĩcation with his brother.

To the iiijth, he answereth as afore, and no otherwise can he answere.

To the $v^{\text {th }}$ Interrogatorie this exa $^{\mathrm{d}}$ answered, that there hath bẽn lres sent betwene hym and Mr. More to and fro. Upon a iij or thereabouts frõ either of theym to other sen they came to the Towre, touching the matiers specified in this Interrogatorie. And declaring the cõtents and effect of the same as ferre as he can remẽbre, saith that he remẽbreth not theffect of any of the letters that either he sent to $\mathrm{M}^{\mathrm{r}}$. More, or that he receaved of $\mathrm{M}^{\mathrm{r}}$. More, before the first being of the counsaill here with this exam ${ }^{t}$, but he doth well remêbre that there were lires sent to and frõ betwene hym and $\mathrm{M}^{\mathrm{r}}$. More before that tyme; and the firste occasion of writing betwene theym pceded first of $\mathrm{Mr}$. More; and nowe being better remẽbred saith that theffect of the first lire that $M^{r}$. More did write unto hym after they cam to the Towre, was to knowe theffect of this depots answere, which he had made to the counsaill in the matier for the which he was first comitted to the Towre; and then the rñdent signified unto hym by his lires what answere he had made theym. Exam̃ed whether he doth remẽbre theffect of any other lĩes that went betwene hym and $\mathrm{M}^{\mathrm{r}}$. More before the first being of the consaill with theym, saith no. And further exam ${ }^{\mathrm{d}}$ what lres went betwene theym syns that time, saieth that sone after that the consaill had bene here firste to examyne this rẽdent, George, $M^{r}$. Lieutenant's s̃vant, shewed this $\operatorname{exa}^{d} a$ lie which Mr. More had directed to his daughter Maistres Rop; theffect whereof was this, that whan the consaill had purposed unto hym the mateer for the which they cam for, he said that he wold not dispute the King's title, and that Mr. Secretarie gave hym good words at his depture; and that is all that he can remibre of theffect of the same lre ; and by the occasion of that lire this rñdent wrote to $\mathrm{Mr}$. More a lre to knowe a more cleareness of 
his answere therin, which tre he dyd sende hym by the said George. And therupon he receaved a tre agein frõ the said $\mathrm{M}^{\mathrm{r}}$. More by the hand of the said George, concerning his answere, but what the same was he saith he hath not in his remẽbrance. And after a deliberate tyme, about thre or iiij daies, this rẽdent calling to his remẽbrance the wordes that his brother Robert Fissher had spoken unto hym long before, viz. howe that the côens did stik and woll not suffre the said statute to passe, onlesse this worde maliciouslie were putt in it, wrote a tre côteyning the same wordes in effecte to $M^{r}$. More, adding this, that $y f$ this worde maliciouslie were putt in the saide statute, he thought it shulde be no daunger yf a man did answere to the question that was purposed unto hym by the counsaill after hys owne mynde, so that he did not the same maliciouslie. But he saith he nothing required or demanded in the said tres the advyse or counsaill of $\mathrm{Mr}^{\mathrm{r}}$. More therein, as he is sure that the same $\mathrm{M}^{\mathrm{r}}$. More hymself wolde testifie yf he be examed. And therupon (as this deponẽt thinketh) $M^{r}$. More supposing that this rũdents answere and his shulde be ṽy nyghe and like, and that the counsaill therby wolde thinke that the tone of theym had taken light of the tother, wolde that the same suspicion shulde be avoyded. And therupon wrote a tre to this rũdent accordinglie.

Further exam ${ }^{\mathrm{d}}$ whether any other tres or intelligence were betwene theym, saith, that soone after the last being of the counsaill in the Towre, and after the taking away of Mr. More's bokes frõ hym, the said George cam to this depot, and told hym that $\mathrm{M}^{\mathrm{r}}$. More was in a pecke of troubles, and that he desired to have either by writing or by worde of mouthe certain knowlege what answere this rẽdent had made to the counsaill. And therupon this rẽdent wrote unto hym a tre that he had made hys answere according to the statute, which côdempneth no man but hym that speketh maliciouslie against the king's title, and that the statute did cõpelle no man to answere to the question that was purposed hym, and that he besought theym that he shulde not be cõstrayned to make further or other answere than the said statute did binde hym, but wolde suffie hym to enjoye the benefite of the same statute, which was all theffect of the said tre as ferre as this depot doth remibre.

And saith further, that he doth not rembre any other tres or message sent frõ hym to Mr. More, or frõ Mr. More to hym syns that tyme, nor theffect VOL. XXv. 
of any other, or message going betwene theym at any tyme other than are before exp̃ssed.

To the rj. vij. viij. ix. x. xj. xij. xiij. xiv. xv. xvj. and xvij. in ${ }^{\text {ts }}$ he hath answered before, and otherwise he can not answere to the same, as he saith.

To the xriijth he saith, and answered, No; he knoweth where none is.

To the xix ${ }^{\text {th }}$ he saith, that they were all brent as soone as he hadde redde theym. And to thintent that theffect therof shulde have bên kept secrete yf it mought be; ffor he was lothe to be repved of his pmise made to $\mathrm{M}^{\mathrm{r}}$. Liewtenlante that he wolde not doo that thing for the which he might be putt in blame. Albeit yf that there were more in the said tres than is before touched, he is sure it was nothing els but exhortacions either of other to take patience in their adversite, and to call [upon」God for Gc̃e and p̃yng for their enemies, and nothing els that sluulde herte or offende any man erthely, as he saith.

To the $\mathrm{xx}^{\text {th }}$ he answereth, that he receaved no other tres than afore touched.

To the $\mathrm{xxi}^{\text {th }}$ int. he saith, that he receaved the same boke frõ Edwarde White by thande of the said George, in the tyme spc̃fied in this Interrogatorie.

To the $x x^{\text {th }}{ }^{\text {in }}$ in he saith that he remẽbreth no cõication betwene hym and Edwarde White, but he saieth that there was certain cõication betwene Wilson and hym about the tyme that they redde the saide statutes, and saith that he threppened upon this rẽdent that the counsaill had purposed unto this rêdent ij poyntes, and this rẽdent sayd that he rem̃bred not there was but one, which was this, howe the counsaill were sente hether to knowe his opinion towching the statute of Sup̃eme bedde, and no other did he remorbe that they shulde purpose unto hym; and said further, that Wilson said that he stode behinde the doore and harde ptely what this rẽdent did answere unto theym; and howe he harde Mr. Bedyll's reasons that he made than; and saith that after that the said Wilson had redd the said statutes to this rëdent ones or twyes, this rẽdent caused theym to be brende because he thought that $y f M^{r}$. Lieuetenant had founde them with this exam ${ }^{\imath}$ he wolde have made moche busyness therupon.

To the xxiijth in $\tilde{t}$ he saith that he doth not remẽbre that ever he declared 
to Wilson or to any man what answere he was disposed to make, what soever cõication were betwene theym thereof.

To the xxiiij he saith that he received no such tres to his knowlege or remẽbrance, but one that Erasmus dyd sende unto hym, which this rẽdent's brother Rob ${ }^{t}$ Fissher showed first to $\mathbf{M}^{\mathrm{r}}$. Secretarie or it cam to hym.

To the $x \times v$ and $x x^{i t h}$ he saieth that George aforenamed brought hym worde sen the last sitting of the counsaill here, that he harde saye of Maistres Rop that this rẽdent was made a Cardinall; and than this rẽdent said in the psence of the said George and Wilson, that yf the Cardinall's hatt were layed at his feete he wolde not stoupe to take it up, he did set so little by it.

To the $x x v i j{ }^{\text {th }}$ he saieth that he receaved no other tres touching the said busynes.

To the xxviijth int he saieth that he receaved no suche fres nor message to his knowlege or his rembrance.

To the $\mathrm{xxix}^{\text {th }}$ he saith that he wrote oftentymes tres touching his diett to him that pvided his diett, as to Robt Fissher while he lived, and to Edward White ; and a tre to my Lady of Oxford for her cõforte ; and łres of request to certain of his frends that he might paye Mr. Lieuetenant for his diet, to whome he was in gte dett, and he was in grte nede.

'To the $\mathrm{xxx}^{\text {th }}$ he receaved certain money of eche of theym according to his request, and no other answere as he saith.

Reexam ${ }^{\mathrm{d}}$ whether there were any suche cõfederacie or cõpaction betwene this rẽdent and his s̃vant Wilson and the said George, that the saied côveying of tres and messages to and fro shulde be kept close yf they were examed therof; saith they were agreyed so together to kepe the same as secrete as they might.

Jo. Roffs. 